\title{
Pět klíčových indikátorů udržitelného rozvoje: nástroj pro vzdělávání a osvětu veřejnosti
}

\author{
Svatava Janoušková, Tomáš Hák, Bedřich Moldan
}

Envigogika 12 (1) - Recenzované články/ Reviewed Papers

Publikováno/Published dne 25. 3. 2017

DOI : $\underline{10.14712 / 18023061.536}$

\begin{abstract}
Abstrakt
Strategie udržitelného rozvoje oslaví v letošním roce třicetileté výročí své existence (1987). Navzdory tomu je dosud koncepce globálně jen málo pochopena veřejností a jen u malé části populace vyvolává „public sentiment", tedy pocit sounáležitosti. Článek se zamýšlí nad př́činami tohoto stavu a nad tím, jak situaci změnit. Stále nevyužitý potenciál pro prezentaci principů a základních myšlenek udržitelného rozvoje mají indikátory. Ty mohou plnit roli informační, osvětovou i edukační a mohou tak napomoci společnosti celou koncepci lépe pochopit, což je pro její všeobecnou akceptaci zásadní. Článek definuje obecné vlastnosti, které by indikátory udržitelného rozvoje měly mít, což jsou mj. tematická a indikátorová relevance; navrhuje pak sadu pěti klíčových indikátorů reprezentujících hlavní dimenze udržitelnosti - lidé, planeta, prosperita, mír a partnerství.
\end{abstract}

\section{Klíčová slova} veřejnosti

Udržitelný rozvoj; indikátory; relevance; hodnocení udržitelnosti; vzdělávání a osvěta

\section{Abstract}

Sustainable Development strategy is going to celebrate its 30th anniversary this year (1987). Despite its long existence it is a concept very little understood globally and causing public sentiment just at a small part of population. The article thinks about the causes and ways to improve it. It is indicators that have an underused potential for presentation sustainability principles and ideas. The sustainability indicators may serve as informative, educational and public enlightenment tools and assist in understanding of the whole concept - an instrumental condition for its embracing. The article defines general qualities of the indicators, as inter alia thematic relevance and indicator relevance, and proposes a set of five key indicators representing main dimensions of sustainable development: People, Planet, Prosperity, Peace and Partnership.

\section{Key words}

Sustainable development, indicators, relevance, sustainability assessment, public education and awareness 


\section{Udržitelný rozvoj - pojem a koncepce}

Udržitelný rozvoj je koncepce (strategie) slavící v letošním roce třicet let své existence. Takové výročí si již zaslouží rozbor toho, kam se společnost v chápání této koncepce dostala, zda je udržitelný rozvoj idea stále aktuální a zda ji nové iniciativy jako Cíle udržitelného rozvoje OSN dále rozvíjejí.

Myšlenka udržitelného rozvoje byla poprvé uvedena ve zprávě „Naše společná budoucnost“ z r. 1987, kterou vypracovala Světová komise pro životní prostředí a rozvoj pod vedením tehdejší norské premiérky Brundtlandové (WCED, 1987). Cílem práce Komise ustanovené OSN bylo odstranit rozpor mezi hospodářským růstem a účinnou ochranou životního prostředí v globálním měřítku, který se jevil jako zcela zásadní. Zpráva přišla s pojmem a do určité míry již také koncepcí udržitelného rozvoje a vymezila jeho obsah dodnes používanou definicí: „Udržitelný rozvoj je takový rozvoj, který naplňuje potřeby současné generace, aniž by ohrozil schopnost generací přištích naplnit své potřeby" (WCED, 1987).

Uplynulých třicet let bylo naplněno širokým úsilím tuto jednoduchou, avšak nepř́liš přesnou a pro praxi těžko uchopitelnou definici prohloubit, doplnit, operacionalizovat a především seznámit s celou koncepcí veřejnost, aby došlo k realizaci navrhovaných opatření. První pokus byl učiněn na Summitu Země v Riu de Janeiro v r. 1992, který přinesl velmi rozsáhlý návod na implementaci udržitelného rozvoje v podobě tisícistránkové Agendy 21. Koperacionalizaci termínu a koncepce udržitelného rozvoje došlo, ale uchopitelnost tohoto globálního vymezení v běžné praxi - např. pro prosazení koncepce v politikách, prezentaci $v$ médiích nebo v osvětě veřejnosti - byla díky rozsahu i formě dokumentu velmi malá. Koncepce, případně s ní související politika, je totiž tím přijatelnější, čím je jednodušší, resp. méně komplexní, a čím emocionálně významnější informaci nese (Boushey, 2010). Také z tohoto důvodu - s vysokou pravděpodobností - významnou roli v řadě zemí sehrála spíše místní Agenda 21 (Local Agenda 21), která dala koncepci udržitelného rozvoje $v$ podmínkách komunity, obce či regionu, ale také z pohledu realizátora MA21 (municipalita, NNO, byznys, dárcovské organizace, jedinci, atp.), konkrétnější a pro veřejnost uchopitelnější podobu. Zpráva však uvádí, že zájem o MA21 v mnoha zemích v současnosti upadá v souvislosti s tím, jak se ve vztahu ke globálním sociálním, environmentálním i ekonomickým problémům objevují nové koncepty (Dodds, Schneeberger \& Ullah, 2012). Ve Spojených státech se dokonce ještě čtvrtstoletí po Konferenci v Riu (1992) objevují kampaně na úrovni jednotlivých států federace i ve městech proti implementaci MA21 s tím, že její principy jsou v rozporu se základními svobodami občanů (viz např. Frick et al., 2015). To ukazuje, že koncept MA21 stále umožňuje cíle udržitelného rozvoje efektivně prosazovat, ale pouze za předpokladu, že se v rámci tohoto konceptu řeší dílčí, pro komunitu srozumitelné a důležité problémy s udržitelným rozvojem spojené. Pokud dostatečně atraktivní nejsou, pak se mohou snadno prosadit iniciativy, které upozorňují na možné ohrožení svobody jedince (kvůli principům jako předběžná opatrnost, rovnost atd.). Je nutné si uvědomit, že implementace strategie udržitelného rozvoje na místní úrovni nijak definici udržitelnosti v globálním kontextu nerozvíjí či nezpřesňuje, naopak ji zpravidla nadále tematicky rozmělňuje. Některé analýzy dokonce naznačují, že tato vágnost se stala jednou z překážek aplikace Agendy 21 v globálním měřítku (viz např. EC, 2002, UNECE, 2016).

Konference OSN o udržitelném rozvoji (tzv. Rio+20) v r. 2012 rozšírila původní koncept tři pilířu (sociálního, environmentálního a ekonomického; nově pojmenovaných lidé, planeta a prosperita) o další dva - mír a partnerství (blíže viz UN, 2002). Důvodem byla skutečnost, že cílů udržitelnosti, jakkoli nepřesně definovaných, nelze dosáhnout bez spolupráce - v rámci jednotlivých zemí a např́č mezi nimi - a že je nelze naplnit tam, kde 
válečné konflikty brzdí či znemožňují jakékoli snahy o rozvoj společnosti. Rozšiření definice o další dvě dimenze však př́liš nenapomohlo ani k operacionalizaci pojmu udržitelný rozvoj $\checkmark$ globálním měřítku, ani $\mathrm{k}$ lepšímu pochopení celé koncepce. Jednotlivé dimenze jsou definovány velmi obecně a při jejich bližší analýze se, podobně jako je tomu u Agendy 21, musí pro lepší pochopení do těchto obecných definic nutně promítnout konkrétní cíle daných zemí, regionů či municipalit. To je zřejmé již jen ze skutečnosti, že sama Evropská unie převedla tyto myšlenky do konkrétních cílů, které chce $v$ rámci udržitelnosti dále řešit (EC, 2002): „With an objective so all-embracing as sustainable development, it is imperative to divide the ultimate aim into smaller, achievable steps. With this in mind, the EU has identified a number of major threats as the initial thrust of its strategy" 1 . Situace se tedy oproti Agendě 21 nijak zásadně nezměnila. Operacionalizace koncepce a přiblížení významu udržitelného rozvoje veřejnosti probíhá tak, že se ve všech dimenzích stanoví priority (nejdůležitější témata či cíle) pro různé úrovně - nadnárodní, národní, místní. Vertikální propojení jednotlivých úrovní je založeno na předpokladu, že jednání lidí na lokální úrovni přispívá ke globálnímu blahobytu i ke globálním problémům a naopak globalizace má mnohočetné dopady až na úroveň místních komunit. Dimenze udržitelnosti "partnerství" a "mír" jsou nejčastěji realizovány prostřednictvím zahraniční (rozvojové) pomoci vyspělých zemí. Lze však předpokládat, že rozvojová pomoc není $v$ očích veřejnosti spojena s udržitelným rozvojem téměř vůbec, nebot' celkové povědomí o rozvojové pomoci je mezi lidmi velmi malé (viz např. McDonnell et al. 2003; Riddell 2007; Spencer et al., 2010). Navzdory snahám tedy operacionalizace (globální) koncepce udržitelného rozvoje nebyla zatím úspěšnější, než tomu bylo u Agendy 21 , a rozšíření o dva další pilíře celé globální vymezení UR z hlediska praktického využití (prosazení koncepce $v$ politikách a konkrétních opatřeních, jeho prezentace $v$ médiích i v osvětě veřejnosti) spíše zkomplikovalo.

Rio+20 uzavřelo toto dlouholeté úsilí formulací globálních Cílů udržitelného rozvoje, jež príjal summit OSN v New Yorku v záŕí 2015. Tak bylo na nejvyšší úrovni schváleno 17 globálních Cílů udržitelného rozvoje (Sustainable Development Goals - SDGs) specifikovaných 169 podcíli, a to vše zarámováno časovým horizontem r. 2030 (viz rezoluce Valného shromáždění OSN přijatá summitem s názvem „Měníme náš svět: Agenda udržitelného rozvoje do roku 2030“) (UN, 2015).

Obsah koncepce udržitelného rozvoje stále vychází z tezí Naší společné budoucnosti, ale $v$ průběhu svého vývoje se poněkud proměnil. Environmentální dimenze koncepce, která původně přinejmenším svým étosem dominovala, se stala jedním ze tří rovnocenných piliřů ekonomického, sociálního a environmentálního rozvoje, a v posledním vývoji dokonce jedním z pěti základních témat - lidé, planeta, prosperita, mír a partnerství. To představuje ucelený a velmi komplexní rámec civilizačního rozvoje, který je univerzální v tom smyslu, že platí pro všechny světové regiony, pro vyspělé i rozvojové státy bez rozdílu. SDGs tak jsou považovány za fundamentální rozvojové paradigma, a to nejen vládami jednotlivých států a Evropskou unií, ale i dalšími vrcholnými mezivládními politickými strukturami, jako je napríklad OECD (organizace 34 průmyslově vyspělých států) nebo G 77 ( $v$ rámci OSN působící skupina více než 130 rozvojových zemí a Čína). Hlásí se $\mathrm{k}$ němu i představitelé velkých společenských skupin, jako je průmyslový a obchodní sektor, akademická komunita, nevládní organizace či místní samosprávy. Je všeobecně přijímáno vyspělým i rozvojovým světem i napříc celým politickým a společenským spektrem. Formulací globálních Cílů udržitelného rozvoje vyvrcholil vývoj koncepce, která je jimi definována, a je dále konkretizována specifickými požadavky. Víme, čeho je třeba 
dosáhnout. Nyní tedy jde o co nejúplnější a nejhladší naplnění uvedených Cílů a dílčích cílů. Na jaké bariéry může implementace narazit?

Lze očekávat, že implementace SDGs z hlediska zapracování do politik, prezentace v médiích i vzdělávání veřejnosti bude narážet na staré problémy, nebot' se potýká se stejnými či podobnými nedostatky, jako dosavadní vymezení udržitelného rozvoje. Dokument obsahuje přiliš mnoho obecně definovaných Cílů a podcílů, které je velmi složité operacionalizovat; je určen všem - vládám jednotlivých zemí ratifikujících úmluvu, nadnárodním uskupením, občanské společnosti, soukromému sektoru; nevylučuje žádnou geografickou oblast atd. Přitom kulturní a sociální rozdíly mezi zeměmi přijímajícími závazek SDGs jsou významné. To vše směřuje ke stejnému postupu při implementaci SDGs - jež Ize vysledovat již na řadě vznikajících dokumentů - a který nepřispěje k lepšímu pochopení koncepce udržitelného rozvoje, naopak nutně opět povede $k$ jeho rozmělnění (viz např. Weitz et al., 2015; Janoušková et al., 2016; O'Connor et al., 2016). Otázkou tak i nadále zůstává, jak udržitelný rozvoj, resp. SDGs prezentovat a zda je vůbec realistické komunikovat takto komplexní strategii, a to dokonce $v$ globálním měřítku, laické veřejnosti.

\section{2. „Public sentiment“ - nutná podmínka pro prezentaci udržitelného rozvoje}

Úspěch SDGs jako nově zformulovaného nástroje implementace udržitelného rozvoje bude významně záviset na tom, zda lidé - jednotlivci i komunity nejrůznějších rozměrů a podob - vezmou Cíle za své, ztotožní se s nimi a budou je považovat za hodny úsilí je plnit. To vystihl již Abraham Lincoln: „Public sentiment is everything. With public sentiment, nothing can fail. Without it, nothing can succeed“2 (Angle, 1991). S tímto názorem se ztotožňuje řada odborníků provádějících výzkum v oblasti prosazování normativních konceptů ve společnosti (viz např. Paxton 2008; McDonnell et al. 2003; Riddell 2007; Spencer et al., 2010).

Závěry těchto autorů podporují také výsledky psychologických, resp. neuropsychologických výzkumů. Ty konstatují, že emocionální význam informace je pro upoutání pozornosti naprosto zásadní a souvisí také s ochotou jedince si danou informaci zapamatovat - naučit se ji. Mozek je biologicky naprogramován tak, aby přednostně věnoval pozornost tomu, co nás může potenciálně ohrozit. To se projevuje nejen $v$ tom, že $v$ našem okolí vnímáme nebezpečí působící naše možné fyzické ohrožení, ale například rovněž tím, že věnujeme pozornost řeči těla či výrazům obličeje člověka, s nímž komunikujeme. Tato nevědomá strategie nám napomáhá nejen přežít, ale také uspět ve společnosti (Wolfe, 2001). Emocionálně laděná informace má navíc pro dotyčného jedince určitou "barvitost", která způsobuje, že si informaci jedinec lépe zapamatuje, a navíc si ji pamatuje delší dobu (LeDoux, 1996). Emocionálně laděná informace nás tedy, aniž si to plně uvědomujeme, povzbuzuje $\mathrm{k}$ tomu, abychom si ji zapamatovali, a dokonce nás často motivuje k doplňování dalších, s ní souvisejících informací, či k vykonání nějakých konkrétních skutků.

Z toho vyplývá, že emocionálně laděná informace je podstatným předpokladem rozvoje kladného citového vztahu veřejnosti (public sentiment) ke konceptu či strategii udržitelného rozvoje. Pokud je pak taková emocionálně laděná informace dostatečně silná,

\footnotetext{
2 Public sentiment $=$ pozitivní veřejné mínění, kladný vztah veřejnosti ( $k$ dané věci). „S pozitivním
} vztahem veřejnosti nic nemůže selhat. Bez něho se nic nemůže podařit." (Angle, 1991). 
jsme rovněž motivovaní $k$ aktivitě, jejímž cílem je cosi naplnit. Jde-li tedy o to, veřejnost nejen informovat nebo poučit, ale změnit rovněž její postoje či hodnotovou orientaci a z nich vyplývající chování tak, aby odpovídaly principům a cílům udržitelného rozvoje, je nutné ukázat cestu, jak to udělat. Přitom tato cesta nemá být př́liš komplikovaná pro pochopení.

Současná globální situace je poznamenána řadou krizí, které výrazně pocitúuje mnoho obyvatel na celém světě. Lidé ve většině zemí jsou už od $r$. 2008 v různé míře zasaženi pocitem či skutečným ohrožením celosvětovou finanční krizí, jež je spojena s neustálenou ekonomickou situací a nejasným výhledem do budoucnosti. Pocit ohrožení je také podporován terorizmem či rozsáhlou migrační vlnou. Veřejnost stále výrazněji vnímá také environmentální hrozby, na prvním místě spojené se změnou klimatu a jejími dopady, jako jsou extrémní změny počasí, ale i další fenomény, mezi něž patří ničení divoké přírody, nedostatek zdrojů vody či znečištění prostředí. Tyto globální problémy jsou odborníky považovány za významné (viz např. World Economic Forum, 2016) a není proto překvapující, že jako emocionálně významné informace upoutávají zájem veřejnosti. Vzhledem k tomu, že řada těchto událostí má bezprostřední vztah $\mathrm{k}$ Cílům udržitelného rozvoje, nabízí se zde možnost využít zájmu o daná témata a prezentovat SDGs veřejnosti.

Veřejnost však také potřebuje srozumitelně představit možnosti, jak se v dané situaci orientovat a jak postupovat při snižování reálných nebo potencionálních rizik. Pokud by se nabídla smysluplná alternativa ke stávajícím, většinou neudržitelným, vzorcům ekonomického a sociálního vývoje v národním i mezinárodním měřítku, zdá se, že nedostatek zájmu a motivace $k$ řešení (tedy public sentiment) by nebyl zásadní překážkou pro úspěšnou implementaci strategie udržitelného rozvoje. Jsou však např́íklad aktuální globální Cíle udržitelného rozvoje takovou reálnou alternativou? Poskytují dostatečnou motivaci a orientaci, a potřebné povědomí o tom, co je jejich podstatným obsahem, k čemu celkově směřují?

\section{Možné řešení: využití indikátorů udržitelného rozvoje jako didaktického nástroje}

Bývalá výkonná ředitelka UNEP3 E. Dowdeswellová při jednom ze seminářů na půdě OSN před mnoha lety ( $v$ r. 1993) poněkud kriticky komentovala uspokojení nad všeobecným přijetím koncepce udržitelného rozvoje: „Do povědomí lidí se po Stockholmské konferenci ( $\vee$ r. 1972) a v následujících letech podařilo dostat pochopení zásadního významu environmentálního rozměru lidského a civilizačního rozvoje. Obávám se však, abychom toto povědomí nerozpustili v poněkud neuchopitelné koncepci udržitelného rozvoje". Dosavadní zkušenost $s$ vývojem koncepce udržitelného rozvoje ukazuje, že i přes rozsáhlou rétoriku vedoucích představitelů, jíz se plní summity a deklarace OSN, OECD či EU, i přes usilovnou práci mnohých výzkumníků a pedagogů nemá široká veřejnost jasnou představu o tom, co udržitelný rozvoj znamená (viz např. Petrie, 2007), nebo si myslí, že definice udržitelného rozvoje není pro praktická opatření př́liš vhodná (viz např. McCann, 2011).

Mnoho teoretiků se $z$ tohoto důvodu snaží předložit co nejúplnější vědecky propracovanou definici udržitelného rozvoje. Formulací a rámců je $\mathrm{k}$ dispozici bezpočet, zdůrazňují všemožné vazby a souvislosti, synergie apod. (viz např. Kates et al., 2005). Abychom však získali na svou stranu klíčově důležitý public sentiment, teoreticky bezchybné definice př́liš nepomohou, stejně jako přesné, ale nepř́liš srozumitelné formulace včetně

3 United Nations Environment Programme - Program OSN pro životní prostředí. 
těch, které jsou předkládány $v$ deklaracích, rezolucích a jiných oficiálních dokumentech. Je zapotřebí najít způsob, jak lidi přesvědčivě a pochopitelně oslovit.

Navrhujeme, např. po vzoru místní Agendy 21, zdůraznit dobře pochopitelné, byt' dílčí aspekty, a vycházet $z$ potřeby řešení aktuálních problémů. Spíše než neuchopitelné holistické pojetí je třeba zaměřit se pragmaticky na konkrétní otázky a nabídnout řešení, která koncepce udržitelného rozvoje obsahuje. Musí ovšem postihnout zásadní a neopominutelná témata, která jsou vyjádřena pěti dimenzemi tvořícími základ koncepce udržitelného rozvoje, aby nedošlo $k$ jeho zkreslení či neúnosnému ochuzení. Zároveň je nutno realisticky vycházet z úrovně znalostí a pochopení dané věci, které mohou být $v$ různých zemích velmi odlišné $v$ závislosti na tom, jak byla strategie až dosud prosazována. Efektivním způsobem, kterým se dají uvedené základní principy i celá idea udržitelného rozvoje sdělit, je použít vhodné indikátory4. Mají roli informační, osvětovou a edukační a mohou tak pomoci tomu, aby společnost celou koncepci lépe pochopila. Pochopení - a přijetí - této koncepce veřejností je pro její další vývoj zcela zásadní.

Indikátory a indexy jsou důležitými nástroji, které převádí informace o složitých jevech do jednoduchého a jednoznačného sdělení, jež Ize snadno interpretovat (Stanners et al., 2007). Aby však mohly indikátory či indexy takto sloužit, musí splňovat několik požadavků. Ty do značné míry závisí na tom, kdo má být uživatelem indikátoru. $Z$ pohledu veřejnosti, pro kterou je indikátor informačním a osvětovým nástrojem, je důležitá zejména tematická relevance indikátoru (blíže viz Hák et al., 2012). To znamená, že se indikátor váže k tématu, které vyvolává u veřejnosti zájem (public sentiment). Indikátor se tak stává relevantním proto, že relevantní je samotné toto konkrétní téma udržitelného rozvoje. Kromě toho musí být indikátor prezentován způsobem, který je veřejnosti blízký, tj. srozumitelně (myslí se $v$ tomto prípadě výsledek, nikoli např. srozumitelnost konstrukce indikátoru).

Tematická relevance a srozumitelnost mohou být $v$ očích veřejnosti postačujícími kvalitami indikátoru; z hlediska toho, kdo indikátor vytváří a prezentuje (odborná veřejnost nebo politik), však dostačující nejsou. Další důležitou vlastností indikátoru je totiž tzv. indikátorová relevance. Indikátorová relevance vyjadřuje, zda navržený indikátor charakterizuje (vystihuje, vysvětluje) co nejlépe téma, o kterém přináší informaci (blíže viz Hák et al., 2016). Relevance indikátoru je zde zaručena tím, že indikátor vychází z vědeckých teorií nebo - pokud tyto teorie absentují - je indikátorová relevance zajištěna zavedením sady indikátorů (blíže viz Bunge, 1975; Bunge, 2003). Indikátorovou relevanci vždy musí posuzovat odborníci zabývající se daným tématem; promotér, tedy ten kdo indikátor prosazuje jako nástroj hodnocení, by však měl vždy zajistit, aby k ověření indikátorové relevance došlo. Uživatel indikátoru by měl dále ověrit, zda jsou získané výsledky legitimní (indikátor nikomu nestraní apod.) a důvěryhodné (data jsou přesná a spolehlivá, metodika výpočtu je správná apod.). Pokud jsou všechny tyto kvality indikátoru zajištěny, pak Ize indikátor považovat za vhodný didaktický prostředek. Je třeba mít na paměti, že vždy je primárně nutné vymezit témata, kterými chceme koncept udržitelného rozvoje veřejnosti prezentovat - indikátory jsou pak prostředkem, který danou informaci zprostředkovává.

Podobně, jako se věnuje pozornost jednoduchému vymezení udržitelného rozvoje, existuje také dlouhodobá snaha nalézt vhodné indikátory udržitelného rozvoje. Objevily se dokonce pokusy o vytvoření jediného indikátoru, který by udržitelný rozvoj

4 V tomto článku termín „indikátor” zahrnuje jednoduché i složené indikátory (agregované indikátory, indexy apod.) 
charakterizoval celkově, podobně jako hrubý domácí produkt agregátně (a v obecném povědomí spolehlivě) ukazuje stupeň hospodářského rozvoje. Po nezdařených pokusech kupř́kladu Index blahobytu (Wellbeing Index - IUCN, 2001), Index udržitelného lidského rozvoje (Sustainable Human Development Index - Dahme et al., 1998), atd. - se ukázalo, že různorodá témata a dimenze udržitelného rozvoje jedním indikátorem, resp. indexem pravděpodobně postihnout nelze, nemá-li dojít k neúnosným zkreslením.

Práce na indikátorech však přinesly řadu podnětů a použitelných výsledků pro implementaci koncepce udržitelného rozvoje, které by umožnily propojení tematické relevance (tedy vhodnosti tématu) s indikátorovou relevancí (tedy schopností indikátoru přinést jednoduché a srozumitelné informace o daném tématu). Ukazuje se, že je možné vytvořit indikátory, jimiž se dají charakterizovat základní dimenze udržitelného rozvoje, a které dobře splňují výše uvedené požadavky na kvalitu indikátorů. Navrhujeme proto pro hodnocení a prezentaci udržitelnosti rozvojes zvolit malý počet takových indikátorů, které mohou informovat o naléhavých a lidmi vnímaných problémech, a předložit je veřejnosti. Je však zřejmé, že volba takových indikátorů s ohledem na tematickou a také indikátorovou relevanci nebude jednoduchá. Dle našeho názoru Ize vyjít z některých stávajících indikátorů, přejmout je nebo podle potřeby upravit. $V$ dalším oddíle se proto zamýšlíme nad tím, které indikátory by mohly být pro prezentaci udržitelnosti rozvoje vybrány, čímž chceme především vyvolat diskuzi mezi odborníky a zainteresovanou veřejností. Je totiž zřejmé, že sada indikátorů aktuálně připravená OSN pro reporting Cílů udržitelného rozvoje (IAEG, 2016) nemůže roli potřebného osvětového prostředku plnit (velký počet, někdy nízká tematická relevance či pochopitelnost indikátorů atd.).

\section{Indikátory jako reprezentanti pěti témat udržitelného rozvoje}

\subsection{Téma "Lidé“}

Téma „Lidé“ Ize podle OSN chápat jako téma odrážející se v těch cílech, které se zaměřují na vymýcení chudoby a hladu ve všech jejich formách, na zajištění možnosti plného využití lidského potenciálu pro všechny, a to důstojným a rovným způsobem, ve zdraví a zdravém životním prostředí (UN, 2015). Široce přijímaným názorem je, že dosažení cílů $v$ tomto tématu je možné pouze $v$ podmínkách rovnosti. Fleurbaey et al. (2014) považuje rovnost dokonce za podmínku plynoucí ze samé podstaty udržitelnosti (intrinsic component). Potřeba naplnění rovnosti mezi lidmi se objevuje již ve zprávě komise Bruntlandové, která uvádí, že „....world in which poverty and inequity are endemic will always be prone to ecological and other crises"6 (WCED, 1987). Také ve zprávě ze summitu v J ohannesburgu je rovnost zdůrazňována jako prostředek k dosažení cílů udržitelnosti (UN, 2002). Rovnost je rovněž důležitým průřezovým principem Cílů udržitelného rozvoje (UN, 2015) a je např. aktuálně významně spojována s klimatickou změnou (viz např. Lélé et al., 2011; Fleurbaey et al., 2014). Lze se také domnívat, že prosazování principu rovnosti může vzbudit public sentiment.

\footnotetext{
5 Pod koncept udržitelného rozvoje zde zahrnujme i kvalitu života. Toto zjednodušení je založeno na faktu, že většina používaných indikátorů/indexů vypovídá o současném stavu blahobytu spíše než o udržitelnosti rozvoje, tedy o schopnosti udržovat blahobyt nekonečně dlouho (více viz např. Stiglitz et al., 2009; Neumayer, 2004; ad.)

6 „„....svět, ve kterém mají své místo chudoba a nerovnost, bude vždy náchylný k ekologickým a jiným krizím..." (WCED, 1987).
} 
Termín i koncept rovnosti není jednoznačný: $v$ angličtině se často vyskytují termíny equity nebo equality (rovnost) a justice nebo fairness (spravedlnost), přičemž přesné vymezení těchto termínů většinou absentuje (viz např. Ikeme, 2003). Př́i analýze různých zdrojů se ukazuje, že rovnost je často - ve spojení s koncepcí udržitelného rozvoje chápána ve dvojím základním pojetí. Prvním je rovnost obyvatel jednotlivých zemí nebo jiných celků $v$ dělení zdrojů, $\mathrm{tj}$. např. rovnost ve zdanění př́ijmů nebo $v$ přístupu $k$ prrírodním zdrojům či ke vzdělávání. Druhé pojetí rovnosti vychází z konceptu meritokracie. Tento koncept považuje výkonové faktory - úsilí jednotlivce, jeho aktivitu, schopnosti, výkonnost, píli a zájem - za významnější než faktory dané, jako např́klad pohlaví, věk, národnost, rasová př́slušnost a sociální původ (viz např. Beder, 2000; Ikeme, 2003; Lélé, 2011). Z tohoto pojetí rovnosti vychází také koncept či princip genderové rovnosti.

Využijeme-li tedy jako základní ideu dimenze "Lidé" právě rovnost s jejím možným dvojím pojetím, pak jsou pro propagaci tohoto piliře udržitelnosti potencionálně využitelné dva indikátory: Gini index zpracovaný Světovou bankou (blíže viz WB, 2016) nebo genderově upravené Indexy lidského rozvoje - Gender Development Index (GDI), případně Gender Inequality Index (GII) zpracovaný Rozvojovým programem OSN (blíže viz UNDP, 2016). Oba indexy Ize považovat za etablovaná měřítka7 přijatelná pro indikátorovou komunitu a srozumitelná pro veřejnost (srozumitelná z hlediska interpretace výsledku, nikoliv metodiky výpočtu indikátoru; tedy že např. hodnoty Gini indexu se ideálně pohybují $\checkmark$ určitém rozmezí, nebot' krajní hodnoty znamenají bud' úplnou rovnost, nebo extrémně vysokou príijmovou nerovnost).

\subsection{Téma „Planeta“}

Téma „Planeta“ charakterizuje OSN jako potřebu chránit Zemi před degradací, mj. prostřednictvím udržitelné spotřeby a výroby, udržitelného řízení přírodních zdrojů, opatřeními v oblasti změny klimatu atd. (UN, 2015). Dimenze „Planeta“ tak zahrnuje tři základní okruhy environmentální udržitelnosti: i) vzorce spotřeby a výroby, ii) správa př́rodních zdrojů a iii) poškozování složek prostředí vlivem antropogenní činnosti. Více subtémat a existence více dat a indikátorů činí výběr vhodných indikátorů složitějším, než tomu bylo $v$ předešlém tématu.

V souvislosti s řízeným využíváním zdrojů na Zemi a poškozováním složek prostředí je jako častý indikátor použíána Ekologická stopa (Ecological Footprint - EF) rozvíjená organizací Global Footprint Network. Indikátor má poměrně velkou popularitu jak u části vědecké komunity, tak u veřejnosti - EF přispěl $k$ tomu, že problematika využívání přírodních zdrojů a související poškozování prostředí se díky různým kalkulátorům dostala do centra pozornosti širší veřejnosti (vzbudila tedy public sentiment). O oblibě EF $v$ médiích svědčí nejen množství odborných publikací, ale i publikací určených laické veřejnosti (blíže viz Hák et al., 2012b), a oblíbenost indikátoru dokládají i jeho kritici. Tematická relevance EF by vyhovovala nárokům na indikátor využitelný $\mathrm{k}$ osvětě, problém však tkví v indikátorové relevanci. Řada vědců sice $E F$ využivá jako proměnné při analýze různých témat souvisejících s udržitelností (viz také van den Bergh, 2014), a EF je také zahrnuta např. do Indexu št́astné planety vytvořeného Nadací pro novou ekonomiku (nef, 2012; WWF, 2016), pro část vědecké komunity však EF není indikátorem metodologicky akceptovatelným (viz např. Fiala,

7 Problémy s měřením nerovnosti viz např. Chitiga: Income inequality and limitations of the gini index: the case of South Africa (http://www.hsrc.ac.za/en/review/hsrc-review-november-2014/limitationsof-gini-index) nebo Cowell, F. A. (2000). Measurement of inequality. Handbook of income distribution, 1, 87-166. 
2008; Blomqvist, 2013; van den Bergh, 2014b). Využitelné by tedy byly spiše další indikátory z tzv. footprint family - např́ílad Uhlíková stopa (Carbon Footrpint) vyjadřující zátěž atmosféry skleníkovými plyny, u které není zpochybňována ani indikátorová ani tematická relevance. Indikátor je dobře pochopitelný, nebot jedním číslem prezentuje uhlíkovou náročnost společnosti (a její závislost na fosilních zdrojích). Dalším kandidátem je Materiálová stopa (Material Footprint) informující o spotřebě surovin i zátěži prostředí (Wiedmann et al., 2015).

Existují další potencionálně využitelné indikátory pro prezentaci této dimenze, jsou ale budto př́liš úzce zaměřené (např. indexy kvality ovzduší, indikátory biodiverzity) nebo naopak až př́liš komplexní - např. Index environmentální výkonnosti (Environmental Perfomance Index - YCELP, 2016), Index environmentální zranitelnosti (Environmental Vulnerability Index - Kaly, 2004) atd. Kvůli nízké indikátorové relevanci nebo mizivé šanci na získání public sentiment se proto nehodí.

\subsection{Téma „Prosperita“}

Téma prosperity chápe OSN jako potřebu zajistit, aby všichni lidé mohli žít prosperující a naplňující život, a aby ekonomický, sociální a technologický pokrok probíhal v souladu $s$ prírodními procesy. Definovat prosperitu jednoznačně je však nanejvýš obtížný úkol. Jackson (2009) z Centra pro výzkum udržitelné prosperity ji popisuje v obecném smyslu jako subjektivní pocit, že věci se odehrávají správně, tedy v souladu s naším očekáváním. Tato definice je založena na subjektivních pocitech každého jedince a nelze ji generalizovat. Přesto řada autorů považuje tzv. subjektivní blahobyt (subjective wellbeing) za důležité měřítko kvality lidského života $s$ tím, že př́rodní i sociální kapitál je její neodmyslitelnou součástí a tudíž existuje př́má vazba mezi subjektivním blahobytem a udržitelným rozvojem (Costanza et al., 2007). Měření osobního (subjektivního) blahobytu je tedy jednou $z$ cest $k$ hodnocení prosperity (viz např. OECD, 2013).

Jiné přístupy vycházejí z přesvědčení, že prosperita souvisí s ekonomickým růstem. Vyšší př́jmy jsou spojeny mj. s větší možností volby a tudíž s celkovým zlepšením kvality života (Jackson, 2009). Oblíbený i zatracovaný indikátor Hrubý domácí produkt však vhodným indikátorem prosperity není, jak prosazuje dnes již deset let trvající iniciativa Evropské komise „Beyond GDP“ (EC, 2007), jejíz snahou je vyvolat debatu o správných měřítkách udržitelnosti. Zdá se, že ideální indikátor reprezentující toto téma by měl zahrnovat nejen ekonomickou prosperitu, ale měl by také zohledňovat sociální a přírodní kapitál. Evropská komise, ale také např. OECD (2016), Costanza et al. (2009) atd., uvádějí jako př́klady indexy, které HDP upravují (Index udržitelného ekonomického bohatství Index of Sustainable Economic Welfare, Indikátor skutečného pokroku - Genuine Progress Indicator, Zelené HDP - Green GDP, Indikátor čistých úspor - Genuine Savings/Net Adjusted Savings, nebo Index prosperity - Prosperity Index) a indexy, které do sebe HDP zahrnují (Index lidského rozvoje - Human Development Index a Index štastné planety Happy Planet Index) 8.

Pro indikátory upravující HDP platí - podobně jako pro samé HDP - že výpočet je složitý, ale význam indikátoru je intuitivně pochopitelný (např. růst indikátoru je pozitivním znakem). $O$ tematické relevanci není sporu, nebot́ prosperita je obecně v centru zájmu lidí.

8 Studie uvažuje ještě další indexy (např. EF, LPI), ty jsou však v rámci této publikace diskutovány u jiných pilírư. 
Index prosperity 9 publikovaný nevládní organizací Legatum Institute je komplexním indikátorem s osmi subindexy (ekonomická výkonnost, osobní svobody, bezpečnost, zdraví, vzdělávání atd.) obsahujícími 89 proměnných (Legatum Institute, 2016; Bate, 2009). Prosperitu definuje jako kombinaci bohatství (wealth) a blahobytu či kvality života (wellbeing). Jeho komplexnost však snižuje indikátorovou relevanci; navíc zasahuje i do dalších dimenzí hodnocených jinými indikátory a je obtížně interpretovatelný. $\vee$ záloze tedy je Index lidského rozvoje, již čtvrtstoletí pravidelně publikovaný Rozvojovým programem OSN (UNDP, 2016). Tento složený ukazatel zahrnující zdraví, vzdělávání a ekonomickou výkonnost je mnoha autory považován za ukazatel prosperity, jak ale napovídá již jeho název, hodil by se i pro téma Lidé (např. Syrovátka, 2008; Auerswald, 2011 atd.). Pravděpodobně se tedy na ideální indikátor pro téma prosperita zatím čeká, i když jeho principy jsou známé: zahrnutí zásob nejen toků; zahrnutí aktiv jako jsou veřejné parky, silnice nebo zdraví; zahrnutí nehmotných aktiv jako dovednosti či vědecké nápady atd.; ohledně př́stupu $\mathrm{k}$ jeho měření je ale nutno získat odborný i politický konsenzus (Economist, 2016).

\subsection{Téma „Mír“}

Toto téma OSN charakterizuje jako potřebu podpory mírové, spravedlivé a inkluzivní společnosti prosté strachu a násilí, a konstatuje, že "udržitelný rozvoj není možný bez míru a mír není možný bez udržitelného rozvoje“ (UN, 2015). Definice míru není doposud konsenzuálně vymezená (Royce, 2004), v řadě studií je však mír chápán jako absence konfliktu v konkrétním místě. Absence konfliktu přitom znamená, že různé státy vůči sobě navzájem nepoužívají ozbrojené síly a uvnitř států se skupinové zájmy neprosazují násilnou cestou. Podobně jako je tomu u prosperity, i pro posuzování míru jsou využívána jednak kvalitativní - subjektivně koncipovaná - měření (zjištúující např. obavy z kriminality) a jednak kvantitativní údaje (např. výdaje na armádu).

Indexem využitelným pro měření míru, jenž má dlouholetou tradici, je Index svobody ve světě (Freedom in the World Index) zpracovávaný institucí Freedom House. Téma míru je pro veřejnost tématem zásadním, tematická relevance indikátoru je nesporná, což by indikátor předurčovalo $\mathrm{k}$ tomu, aby byl dobrým osvětovým nástrojem. Spornou je ovšem indikátorová relevance. Kritika se týká zejména způsobu získávání dat, který je založen na subjektivních názorech expertů - řada vědců poukazuje na zkreslení výsledků ve prospěch zemí, jež mají dobré vztahy se Spojenými státy (viz např. Cooley et al., 2015; Steiner, 2016). Za mnohorozměrný index dotýkající se mj. problematiky míru Ize považovat také Index zranitelných zemí (Fragile States Index10) organizace Fund for Peace. Jeho využitelnost pro hodnocení tématu mír je však obtížná, protože index zahrnuje také indikátory ekonomické, které se týkají jiných témat v rámci koncepce udržitelného rozvoje (např. chudoby, ekonomického růstu). Za indikátor lze považovat i Rozpočet mírových operací OSN, který reflektuje bezpečnostní situaci ve světě (přestože udržování míru není př́mo zakotveno $v$ Chartě OSN, mírové mise jsou zásadním nástrojem mezinárodního

\footnotetext{
9 Česká varianta indexu užívá užší pohled na prosperitu: porovnává, jak se zvyšují výdělky zaměstnanců a kolik lidí bylo bez práce. Výsledek vznikne jako rozdíl tempa růstu mezd a míry nezaměstnanosti (Holanová, T. (8.2.2016) Česko se vrátilo k prosperitě. Jsme na tom nejlépe od roku 2007, spočítal ekonom. Aktuálně.cz, https://zpravy.aktualne.cz/ekonomika/cesko-se-vratilo-kprosperite-jsme-na-tom-nejlepe-od-roku$\underline{\text { 20/r } ~ 9 a d 5 a 90 c c c 0811 e 5 a 8 d 7002590604 f 2 e / ? r e d i r e c t e d ~}=1483994200$ )
}

10 Původně nesl index název Failed States Index 
společenství k prosazování míru a bezpečnosti11). Problém je samozřejmě s interpretací potřeba zvyšovat výdaje vlastně znamená, že svět je nebezpečnější, zamořený konflikty a zhroucenými státy. Nejslibnější se zatím zdá Index světového míru (Global Peace Index od Institute for Economic and Peace). Tematická relevance indexu je, podobně jako je tomu u Indexu svobody ve světě, velmi dobrá, což souvisí s obecným zájmem lidí o bezpečnost ve světě (např. v souvislosti s cestováním). J istým problémem je pouze komplexnost indexu, která znesnadňuje jednoduchou interpretaci indikátoru. Kromě těchto ukazatelů zaměřených na hodnocení současného stavu by bylo možné uvažovat i o hodnocení budoucích trendů zatím ve vývoji je Index stavu budoucnosti (State of the Future Index - SOFI) (Millennium Project, 2016).

\subsection{Téma „Partnerství“}

Dle OSN „,je zapotřebí mobilizovat prostředky k provádění agendy udržitelného rozvoje prostřednictvím obnoveného globálního partnerství budovaného $v$ duchu posílené globální solidarity a zaměřeného především na potřeby nejchudších a nejzranitelnějších, s účastí všech zemí, všech zainteresovaných subjektů a všech lidí." (UN, 2015). Koncept partnerství zde však není dostatečně operacionalizován: Jde o měření efektivnosti partnerství (správné rozdělení rolí mezi partnery, přizpůsobení mechanismů místním podmínkám, nastavení odpovědností atd.), tedy většinou kvalitativních charakteristik, nebo spíše o měření kvantitativně postihnutelných výsledků aktivit založených na partnerství (Caplan and Jones, 2002). Kritérium indikátorové relevance proto činí výběr složitým - jako zcela vhodný se nenabízí žádný $\mathbf{z}$ dosud zavedených indikátorů (více viz např. Global Partnership for Effective Development Cooperation, 2016).

Moderní rozvojové politiky vyspělých států jsou explicitně založeny na partnerství (viz např. MZV, 2010). Jediným široce dostupným ukazatelem vlivu rozvinutých zemí na země rozvojové je zatím Oficiální rozvojová pomoc (ODA) vykazovaná v absolutním množství finančních prostředků nebo jako podíl na národním důchodu. Je považována za jeden z nejdůležitějších nástrojů pro předcházení světové nestabilitě, konfliktům a extrémní chudobě; zároveň je zřejmé, že zde nejde o pouhý altruismus a že je nutné koncept rozvojové pomoci přeformulavat (např. Carbonnier, 2010; Riegel, 2010; OECD, 2013b). Nelze stále sledovat jen objem pomoci, roli hraje také zvýšení její kvality, což by však vyžadovalo značné reformy $v$ celém systému pomoci (tedy nejen ze strany donorů, kteří mohou zefektivnit své aktivity, ale rovněž ze strany rozvojových zemí, které mohou zlepšit způsob řízení přijímané pomoci) (Vlková, 2009). Jako reakce na toto čistě monetární pojetí hodnocení rozvinutých zemí v jejich přístupu k rozvojovým zemím vznikl Index vstřícnosti k rozvojovým zemím (Commitment to Development Assistance Index) (Roodman, 2004). Zahrnuje sedm oblastí politik rozvinutých zemí - rozvojovou pomoc, mezinárodní obchod, investice, migraci, životní prostředí, bezpečnost a technologie - a pokouší se měřit politiku a aktivity rozvinutých zemí, které napomáhají či naopak omezují rozvoj chudých zemí. Kupř́kladu $v$ oblasti mezinárodního obchodu se měři úroveň obchodní otevřenosti/protekcionismu ve vztahu $k$ dovozům z rozvojových zemí, konkrétně tedy do jaké míry rozvinuté země omezují dovoz produktů z rozvojových zemí na své trhy. Index měří jen vstřícnost donorů, tedy jen cca 40 států, a i pro další metodologické nedostatky není př́liš využíván (Syrovátka a Hák, 2015).

11 Mírové síly Spojených národů obdržely v r. 1998 Nobelovu cenu míru 


\section{Výsledky a závěr}

Zároveň se schválením globálních Cílů udržitelného rozvoje byla Statistická komise OSN pověřena zpracováním vhodných indikátorů pro všech 169 podcílů. $V$ průběhu $r .2016$ probíhala celosvětová diskuze, která by měla v r. 2017 vyústit v definitivní seznam doporučených indikátorů. Ty by měly - na rozdíl od našeho návrhu - co nejpřesněji postihnout celý rozsáhlý komplex globálních cílů. Ve snaze o splnění daného úkolu se seznam rozrostl na přibližně 240 položek, protože pro většinu podcílů je navržen více než jeden indikátor. Výsledný seznam by měl podat co nejúplnější a technicky do detailu propracované vodítko pro hodnocení pokroku v naplňování schválených Cílů udržitelného rozvoje. Je zřejmé, že bez detailních indikátorů pokrok hodnotit není možné a Ize si jen přát, aby soubor indikátorů byl mezinárodně schválen a stal se důležitým nástrojem naplňování koncepce udržitelného rozvoje na globální úrovni. Takovýto postup je samozřejmě na místě, avšak podle našeho názoru nestačí. Tento top-down př́stup musí být pro účinnou implementaci doplněn procesem bottom-up založeným na aktivní spolupráci široké veřejnosti.

Pro osvětu veřejnosti, širokou osvětu a získání public sentiment jsou námi tedy navrženy tyto indikátory: Gini index, Uhlíková stopa, Index lidského rozvoje, I ndex světového míru a Oficiální rozvojová pomoc (viz Tab. 1). Tyto indikátory jsou většinou známy, jsou již používány a jsou dostatečně názorné či pochopitelné nebo mají potenciál vzbudit public sentiment, pokud je politici, odborníci, média atd. začnou běžně používat. Každý z nich se týká důležitých a pro lidi významných skutečností - všechny (pravděpodobně s výjimkou indikátoru Oficiální rozvojová pomoc12) tedy mají vysokou tematickou relevanci. Dobře charakterizují pět hlavních dimenzí udržitelného rozvoje, pro celou koncepci jsou individuálně relevantní a ve svém souboru do velké míry zachycují její podstatné rysy. Některé již vzhledem k relativně častému použivání postupně získaly určitý symbolický význam, který nelze podceňovat - pro získání public sentiment je to velmi důležité.

Tab. 1 Indikátory navržené pro pět dimenzí koncepce udržitelného rozvoje

\begin{tabular}{|l|l|l|l|l|}
\hline \multicolumn{5}{|c|}{ Udržitelný rozvoj } \\
\hline Lidé & Planeta & Prosperita & Mír & Partnerství \\
\hline Gini index & Uhlíková stopa & $\begin{array}{l}\text { Index lidského } \\
\text { rozvoje }\end{array}$ & $\begin{array}{l}\text { Index } \\
\text { světového } \\
\text { míru }\end{array}$ & $\begin{array}{l}\text { Oficiální } \\
\text { rozvojová } \\
\text { pomoc }\end{array}$ \\
\hline $\begin{array}{l}\text { Genderově } \\
\text { upravený } \\
\text { Index lidského } \\
\text { rozvoje }\end{array}$ & $\begin{array}{l}\text { Materiálová } \\
\text { stopa nebo } \\
\text { Ekologická } \\
\text { stopa }\end{array}$ & $\begin{array}{l}\text { Indikátor } \\
\text { čistých úspor }\end{array}$ & $\begin{array}{l}\text { Výdaje na } \\
\text { mírové } \\
\text { operace OSN }\end{array}$ & $\begin{array}{l}\text { Index } \\
\text { vstř́cnosti } \\
\text { k rozvojovým } \\
\text { zemím }\end{array}$ \\
\hline
\end{tabular}

12 Oficiální rozvojová pomoc - indikátor, který v mnohých ohledech nesplňuje požadavky na klíčový ukazatel pro téma Partnerství ani z hlediska indikátorové relevance, je v návrhu pouze z důvodu nedostatku vhodnějšího ukazatele; smyslem je vyvolat diskuzi o potřebě relevantních ukazatelů v této důležité oblasti. 
Pozn. Indikátory zapsané v tabulce kurzivou mohou být zvažovány jako alternativy.

Zároveň platí, že se nejedná o indikátory ideální. Lze očekávat, že se pro daný účel případně uplatní další indikátory, které se v současnosti vyvíjejí nebo se teprve objeví. Příkladem je práce na vyhodnocení prírodního kapitálu, jak probíhá v rámci mezinárodního projektu Waves 13 koordinovaného Světovou bankou, nebo Inkluzivní index bohatství (Inclusive wealth index), vypracovaný pod patronací Univerzity OSN, mezinárodního programu IGHP a UNEP, který spojuje lidský, sociální, přírodní a lidmi vyrobený kapitál do souhrnného indexu bohatství jednotlivých států. Není vyloučeno, že se tyto nebo jiné indikátory stanou natolik populárními, že se budou široce používat. Po věcné a metodické stránce jistě pro to mají předpoklady, pro hodnocení pokroku směrem $k$ udržitelnosti jsou významné (konkrétně mají vysokou tematickou relevanci pro dimenze "planeta" a „prosperita“), avšak teprve praxe ukáže jejich životnost.

Výše jsme uvedli, že pokusy vypracovat pro hodnocení udržitelnosti rozvoje jediný indikátor či index byly opuštěny. Nicméně pokud by se podařilo uvést do života soubor funkčních indikátorů, at́ už podle uvedených návrhů nebo nějak modifikovaně, mohlo by se uvažovat o možnosti spojit je do jednoho indexu. Předtím je však třeba dokončit koncepční i metodické práce na hodnocení pěti základních témat udržitelného rozvoje.

Metodologická poznámka na závěr: Autorský tým je složen ze zástupců (téměř) tř́ generací - každého tedy koncepce udržitelného rozvoje zastihla $v$ jiné etapě profesního $\mathrm{i}$ osobního života. To je pro téma článku významné: jednak proto, že udržitelný rozvoj je koncepcí normativní a náhled různých generací může postihnout rozdílné vnímání její propagace i implementace. Dále proto, že ani termín udržitelný rozvoj, ani jednotlivé dimenze této koncepce zatím nejsou jednoznačně definované, ani dostatečně operacionalizované pro potřeby analýz a hodnocení či dokonce pro potřeby implementace. Četné autorské diskuze a vyjasňování celé koncepce, jejích dimenzí i vhodných indikátorů tak přispěly $\mathrm{k}$ věrohodnosti výsledku tohoto úsilí - konsenzuálnímu návrhu komunikace hodnocení udržitelnosti $v$ globálním měř́tku pro širokou veřejnost. Jeho smyslem je především otevřít diskuzi na toto téma.

\section{Poděkování}

Práce na článku je součástí programu Univerzity Karlovy pro rozvoj vědních oblastí Progres (program Q16 - Environmentální výzkum a program Q46 - Chemie).

\section{Literatura}

- Angle, P.M. (Ed). (1991). The Complete Lincoln-Douglas Debates of 1858. Chicago: University of Chicago Press.

- Auerswald, P. (2011). The coming prosperity: How entrepreneurs are transforming the global economy. Oxford University Press.

13 Waves - Wealth accounting and the valuation of ecosystem services (http://www.worldbank.org/en/news/feature/2015/06/15/waves-faq) 
- Bate, R. (2009). What Is Prosperity and How Do We Measure It? AEI Development Policy Outlook, 3.

- Beder, S. (2000). Costing the Earth: Equity, Sustainable Development and Environmental Economics. New Zealand J ournal of Environmental Law, 4, 227-243.

- Blomqvist, L.; Brook, B.W.; Ellis, E.C.; Kareiva, P.M.; Nordhaus, T.; et al. (2013). The ecological footprint remains a misleading metric of global sustainability". PLOS Biology, 11 (11).

- Boushey, G. (2010). Policy Diffusion Dynamics in America. New York, NY: Cambridge University Press.

- Bunge, M. (1975). What is quality of life indicator? Soc. Indic. Res. 2(1), 65-79.

- Bunge, M. (2003). Philosophical Dictionary. Enlarged Edition. Amherst, New York: Prometheus Books.

- Caplan, K., \& Jones, D. (2002). Partnership indicators - Measuring the effectiveness of multi-sector approaches to service provision. Practitioner Note Series. London: BPD Water and Sanitation Cluster.

- Carbonnier, G. (2010). Official development assistance once more under fire from critics. International Development Policy (1), 137-142.

- Cooley, A. (2015). The emerging politics of international rankings and ratings: A framework for analysis. Ranking the world: Grading the states as a tool of global governance, 1-38.

- Costanza, R., Fisher, B., Ali, S., Beer, C., Bond, L., Boumans, R., ... \& Gayer, D. E. (2007). Quality of life: An approach integrating opportunities, human needs, and subjective well-being. Ecological economics, 61(2), 267-276.

- Costanza, R.; Hart, M.; Posner, S; Talberth,J. (2009). Beyond GDP: The Need for New Measures of Progress. The Paradee Papers/No. 4/ January 2009. Boston University.

- Dahme, K., Hinterberger, F., Schütz, H., \& Seifert, E. K. (1998). Sustainable Human Development Index: A Suggestion for 'Greening'the UN's Indicator. Wuppertal Institute for Climate, Environment and Energy Working Paper.

- Dodds, F., Schneeberger, K., \& Ullah, F. (2012). Review of implementation of Agenda 21 and the Rio Principles. New York: United Nations Department of Economic and Social Affairs.

- EC (2002). The World Summit on Sustainable Development: People, planet, prosperity. Luxembourg: Office for Official Publications of the European Communities.

- EC (2007). Beyond GDP. Measuring progress, true wealth, and well-being. http://ec.europa.eu/environment/beyond_gdp/background_en.html

- Economist (2016). How to measure prosperity. Available at: http://www.economist.com/news/leaders/21697834-gdp-bad-gauge-material-wellbeing-time-fresh-approach-how-measure-prosperity) (cited December 2016). 
- Fiala, N. (2008). Measuring sustainability: Why the ecological footprint is bad economics and bad environmental science. Ecological Economics 67, 519-525.

- Fleurbaey, M., Kartha, S., Bolwig, S., Chee, Y. L., Chen, Y., Corbera, E., Lecocq, F., Lutz, W., Muylaert, M. S., Norgaard, R. B., Okereke, C. \& Sagar, A. D. (2014). Sustainable Development and Equity. In: Climate Change 2014: Mitigation of Climate Change. Contribution of Working Group III to the Fifth Assessment Report of the Intergovernmental Panel on Climate Change. Cambridge University Press, Cambridge, United Kingdom and New York, NY, USA.

- Frick, K.F., Weinzimmer, D., \& Waddell, P. (2015). The politics of sustainable development opposition: State legislative efforts to stop the United Nation's Agenda 21 in the United States. Urban Studies, Vol. 52(2) p. 209-232.

- Global Partnership for Effective Development Cooperation (2016). Indicators and targets. Available at: http://effectivecooperation.org/monitoring-countryprogress/explore-monitoring-data/

- Hák, T., Janoušková, S., Moldan, B. (2016). Sustainable development goals: A need for relevant indicators. Ecological Indicators, 60 565-573.

- Hák, T., Kovanda, J., \& Weinzettel, J. (2012). A method to assess the relevance of sustainability indicators: Application to the indicator set of the Czech Republic's Sustainable Development Strategy. Ecological Indicators 17: 46-67.

- Hák, T.; J anoušková, S., Abdallah, S., Seaford, Ch., \& Mahony, S. (2012b). Review report on Beyond GDP indicators: categorisation, intensions and impacts. Final version of BRAINPOoL deliverable 1.1, A collaborative project funded by the European Commission under the FP7 programme (Contract no. 283024). CUEC Prague, 18 October 2012.

- IAEG (2016). Final list of proposed Sustainable Development Goal Indicators. Report of the Inter-Agency and Expert Group on Sustainable Development Goal Indicators (E/CN.3/2016/2/Rev.1), Annew IV. Available at: http://unstats.un.org/sdgs/indicators/Official\% 20List\% 20of\% 20Proposed\% 20SDG $\% 201$ ndicators. pdf

- Ikeme. J. (2003). Equity, environmental justice and sustainability: incomplete approaches in climate change politics. Global Environmental Change 13, 195-206.

- IUCN (2001). The wellbeing of nations: a country-by-country index of quality of life and the environment. Washington, DC: Island Press.

- Jackson, T. (2009). Prosperity without Growth. Economics for Finite Planet. London: Earthscan.

- Kaly, U.L., Pratt, C.R., \& Mitchell, J. (2004). The Demonstration Environmental Vulnerability Index (EVI) 2004. SOPAC Technical Report 384, 323 pp.

- Kates, R. W., Parris, T.M., \& Leiserowitz, A. A. (2005). What is Sustainable Development: Goals, Indicators, Values and Practice. Environment: Science and Policy for Sustainable Development, Vol. 47 (3), 8-21.

- LeDoux, J. (1996). The emotional brain. New York: Simon and Schuster. 
- Legatum Institute (2015). Legatum Prosperity Index 2016. http://www. prosperity.com .

- Léle, S., \& Jayaraman, T. (2011). Equity in the context of sustainable development. Ministry of Environment and Forests, Government of India.

- McCann, K. (2011). Is the government's sustainable development definition good enough? Guardian. https://www.theguardian.com/local-governmentnetwork/poll/2011/sep/28/poll-sustainable-development-nppf-definition.

- McDonnell, I., Lecomte, H.-B., \& Wegimount, L. (2003). Public Opinion Research, Global Education and Development Cooperation Reform: In Search of a Virtuous Circle. Paris: Organisation for Economic Cooperation and Development.

- Millennium Project, 2015. State of the Future Index. http://www.millenniumproject.org/millennium/SOFI.html\#2015SOFI

- MZV (2010). Koncepce zahraniční rozvojové spolupráce ČR na období 2010-2017. Ministerstvo zahraničních věcí.

- nef (2012). The Happy Planet Index: 2012 Report. A global index of sustainable well-being. New economic foundation, London. https://static1.squarespace.com/static/5735c421e321402778ee0ce9/t/578de9dd2 9687f525e004f1d/1468918241593/2012+Happy+Planet+Index+report.pdf

- Neumayer, E. (2004). Sustainability and Well-being Indicators. Research Paper No. 2004/XX, WIDER, UN University.

- O'Connor, D. et al. (2016). Universality, Integration, and Policy Coherence for Sustainable Development: Early SDG Implementation in Selected OECD Countries. Working Paper. Washington, DC: World Resources Institute.

- OECD (2013). OECD Guidelines on Measuring Subjective Well-being. OECD Publishing.

- OECD (2013b). OECD Insights. Yes, it is time to revisit the concept of Official Development Assistance. http://oecdinsights.org/2013/05/04/yes-it-is-time-torevisit-the-concept-of-official-development-assistance/

- OECD (2016). Better Life Initiative: Measuring Well-Being and Progress. Available at: http://www.oecd.org/statistics/better-life-initiative.htm.

- Paxton, P., \& Knack, S. (2012). Individual and country-level factors affecting support for foreign aid. International Political Science Review, 33(2), 171-192.

- Petrie, J. (2007). Educating For Sustainable Development: A Foundation Document. New Brunswick Education for Sustainable Development Working Group.

- Pillarisetti, J. R. (2005). The World Bank's 'genuine savings' measure and sustainability. Ecological Economics 55(4), 599-609

- Riddell, R. (2007). Does Foreign Aid Really Work? Oxford: Oxford University Press. 
- Riegel, M. (2010). Rozvojová politika EU: Altruismus nebo nástroj k dosažení vlastních cílů? Rozvojovka. http:// www.rozvojovka.cz/analyzy/133-rozvojovapolitika-eu-altruismus-nebo-nastroj-k-dosazeni-vlastnich-cilu.htm

- Roodman, D. (2004). The Commitment to Development Index: 2004 edition. Washington, DC: Center for Global Development.

- Royce, A. (2004). A definition of peace. Peace and Conflict. Journal of Peace Psychology 10(2): 101,101-116.

- Spencer, H., Lindstrom, J., Haddad, L., \& Mulmi, R. (2010). Public Perceptions of International Development and Support for Aid in the UK: Results of a Qualitative Enquiry. Brighton: Institute of Development Studies.

- Stanners, D., Bosch, P., Dom, A., Gabrielsen, P., Gee, D., Martin, J., ... \& Weber, J. L. (2007). Frameworks for environmental assessment and indicators at the EEA. In: Sustainability Indicators-A Scientific Assessment.

- Steiner, N. D. (2016). Comparing Freedom House Democracy Scores to Alternative Indices and Testing for Political Bias: Are US Allies Rated as More Democratic by Freedom House? J ournal of Comparative Policy Analysis: Research and Practice, 18(4), 329-349.

- Stiglitz, J., Sen, A., \& Fitoussi, J. P. (2009). The measurement of economic performance and social progress revisited. Reflections and overview. Commission on the Measurement of Economic Performance and Social Progress, Paris.

- Syrovátka, M. (2008). Jak (ne)měřit kvalitu života. Kritické pohledy na index lidského rozvoje. Mezinárodní vztahy, Vol 43 (1), 9-37.

- Syrovátka, M., \& Hák, T. (2015). Measuring rich-country policies toward the global environment: A critical analysis of the environmental component of the commitment to development index. The Journal of Environment \& Development, 24(1), 105-128.

- UN (2002). Report of the World Summit on Sustainable Development. A/CONF.199/20. Johannesburg, South Africa, 26 August- 4 September 2002. UN: New York.

- UN (2015). Transforming our world: the 2030 Agenda for Sustainable Development. Resolution adopted by the General Assembly on 25 September 2015, A/RES/70/1.

- UNDP (2016). Human Development Report 2015. Available at: http://hdr.undp.org/sites/default/files/2015_human_development_report_1.pdf (cited December 2016).

- UNECE (2016). Sustainable development - concept and action. Available at: (http://www.unece.org/oes/nutshell/20042005/focus_sustainable_development.html).

- van den Bergh, J. C. J. M; Grazi, F. (2014). Ecological Footprint Policy? Land Use as an Environmental Indicator. Journal of Industrial Ecology, 18 (1): 10-19. 
- van den Bergh, J., \& Antal, M. (2014b). Evaluating alternatives to GDP as measures of social welfare/progress. WWWforEurope Working Paper.

- Vlková, I. (2009). Efektivnost rozvojové pomoci jako prostředek pro zvýšení dopadu official development assistance. Acta economica pragensia, 3.

- WB (2016). PovcalNet: an online analysis tool for global poverty monitoring. Available at: http://iresearch.worldbank.org/PovcalNet/home.aspx.

- WB (2016b). Adjusted savings: net national savings (\% of GNI). Available at: http://data. worldbank.org/indicator/NY.ADJ .NNAT.GN.ZS (cited December 2016).

- WCED (1987). Our Common Future. World Commission on Environment and Development, Oxford University Press, Oxford.

- Weitz, N., Persson, Å., Nilsson, M., \& Tenggren, S. (2015). Sustainable Development Goals for Sweden: Insights on Setting a National Agenda. Stockholm: Stockholm Environment Institute.

- Wiedmann, T. O, Schandl, H., Lenzen, M., Moran, D., Suh, S., West, J., \& Kanemot, K. (2015). The material footprint of the nations. PNAS, 112 (20), pp. $6271-6276$.

- Wolfe, P. (2001). Brain Matters: Translating research into classroom practice. USA: ASCD.

- World Economic Forum (2016). The Global Risks Report 2016 (11th Edition). Swizerland, Geneva.

- WWF (2016). Living planet report 2016. Risk and resilience in a new era. WWF International, Gland: Switzerland.

- YCELP (2016). Global Metrics for the Environment: The Environmental Performance Index ranks countries' performance on high-priority environmental issues. Yale University, Columbia University, World Economic Forum.

doc. RNDr. Svatava J anoušková, Ph.D.

E-mail: janouskova@natur.cuni.cz

Katedra učitelství a didaktiky chemie

Univerzita Karlova

Přírodovědecká fakulta

Albertov 3, 12843 Praha 2

www.natur.cuni.cz

doc. PaedDr. Tomáš Hák, Ph.D.

Univerzita Karlova

Centrum pro otázky životního prostředí

J osé Martího 2

http:// www.czp.cuni.cz 
Prof. RNDr. Bedřich Moldan, CSc.

Univerzita Karlova

Centrum pro otázky životního prostředí

José Martího 2

http:/ / www.czp.cuni.cz 